Слободан В. Владушић*

Универзитет у Новом Саду

Филозофски факултет

Одсек за српску књижевност

https://doi.org/10.18485/ai_petrovic_goran.2020.ch3

821.163.41.09-31 Петровић Г.

\title{
ЗАШТО НАМ ЈЕ ПОТРЕБНО НОВО ЧИТАҢЕ ОПСАДЕ ЦРКВЕ СВЕТОГ СПАСА
}

Текст заступа тезу да је Петровићев роман успео да помири два наоко различита начина читања књижевности: епски, који од књижевности тражи одговорност на саморазумевање колектива, и формално-теоријски, који се темељи на доминантном теоријско-поетичком хоризонту очекивања. Како се концепт српске књижевности преображава у духу неолиберализма који у књижевности види робу и/или гест политичког активизма, поставља се питање будуће рецепције романа Ойсaga иркве Свет̄о̄ Сйаса. Да би овај роман задржао свој култни статус, он мора да генерише ново чийане. То ново читање треба да потврди његов статус сазнајног инструмента који говори о нашој (неолибералној) епоси. Завршетак текста доноси

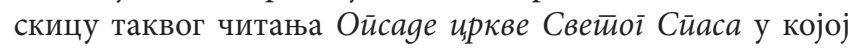
се обраћа посебна пажња на лајтмотив минијайиризације, који је у присутан у овом роману, а који представља одлику наше епохе.

Кључне речи: еп, формално-поетички хоризонт, поетика, неолиберализам, минијатуризација

* svladusic@ff.uns.ac.rs 
Једна од великих тајни српске књижевности с краја 20. века јесте култни статус књиге Oйcaga иркве Све$\bar{u} о \bar{\imath}$ Сйаса Горана Петровића. При том, чини ми се да није довољно рећи како је поменути роман естетски релевантан или чак естетски супериоран, будући да та формулација више констатује такав статус, него што га објашњава. Постоје естетски релевантни романи који немају статус култних романа. С друге стране, не може се рећи ни да је култни статус овог романа повезан само са

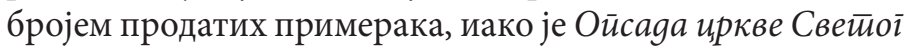
Сйаса свакако спада у групу бестселера. Наиме, постоје и они бестселери о којима након читања нико не размишља или пише.

Култни статус овог романа остаће вероватно загонетка, али ће покушаји одгонетања те загонетке, надам се, још дуго времена бити актуелни. Овај текст је резултат једног од могућих одгонетања. По мом мишљењу, култни статус овог романа последица је чињенице да он истовремено задовољава потребе различитих група читалаца који у књижевности траже различите ствари. Примера ради, године 1997. када је изашло прво издање овог романа, било је много читалаца који су желели да у књижевности пронађу йравеgнију тематизацију националног и културног идентитета, што значи књижевно дело које би тему националног идентитета одвојило од политичких сврставања у погледу грађанског рата у Босни и Хрватској. Тој великој групи читалаца Oūcaga

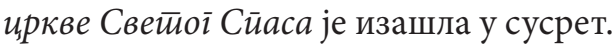

За разумевање успеха Петровићевог романа треба међутим имати у виду и роман Радослава Петковића Суgбина и коментиари (1994). Петковићев роман, овенчан Ниновом наградом у време када је она још увек била награда за књижевност, показује нам да је теоријски 
хоризонт разумевања тадашње српске књижевности у то време био одлучујуће усмерен ка (постмодерном) односу историје и књижевности. Зато вреди забележити и факт да је годину дана пре Петровићевог романа објављен превод књиге Поейика ӣосймоgернизма Линде Хачион, у којој се као један од кључних термина појављује жанр историографске метафикције. Поетичке црте Петро-

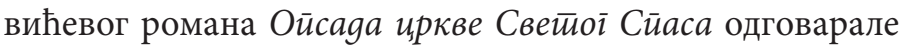
су таквом постмодерном теоријском хоризонту стручније публике, али га је истовремено и полемички доводио у питање. (в. Јовановић, 2012: 611 - 618; в. Владушић 2010: 121 - 130). У случају Петковића, показало се, то није

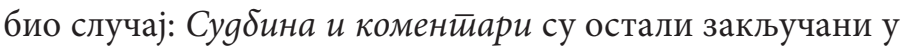
свом времену, што не значи да се овај роман и данас неће

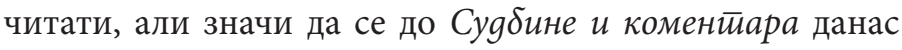
долази преко заинтересованости за постмодернизам, а не обратно.

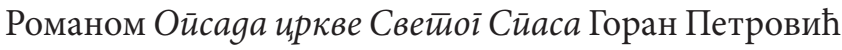
је успео помири две групе читалаца: оне који у књижевности траже дух епа који повезује народ и оне за које семантика форме књижевног дела има врло важну улогу.

Прва, већа група читалаца у књижевности траже обраду важне колективне теме, било да се колектив схвати као национални колектив, било као човечанство у целини. Такав захтев је апсолутно легитиман када је у питању традиција српске књижевности, будући да она у себи носи снажан дух колективитета, али не у смислу да колектив гуши личност појединца, већ, напротив, да појединац/личност прихвата обавезу коју има према колективу. Једноставније речено: српска књижевност је током своје историје имала епске претензије што значи жељу да уједини колектив око књижевног текста. Природа такве жеље се мењала у складу са поетикама и духом времена, али се њено присуство могло осетити у различитим књижевним периодима: од усмене (народне) 
књижевности, преко романтизма (Његош, Бранко Радичевић, Змај), српске модерне и концепта књижевности Јована Скерлића и његове обнове патриотске књижевности. Исти тај однос према колективу осетио се и у Црњансковој идеји о циклусу романа чије су Сеобе биле само први део, те у његовим ставовима о односу колектива и књижевности, ${ }^{1}$ слично као и код Андрића учијим ставовима такође можемо препознати одговорност према колективу ${ }^{2}$, потом у специфичној рецепцији Добрице Ћосића у српском друштву, затим у Пекићевој запитаности о узроцима пропасти српске грађанске класе, те судбине материјалистичке цивилизације уопште. Не би требало заборавити, наравно, ни Кишову опсесивну тему логора, која такође упућује на обавезу коју писац има према колективу, као и на Павићево

1 У једном интервјуу из 1964. године, Црњански на два различита начина одређује однос између писца и колектива. Најпре, на почетку интервјуа, он каже: „За мој књижевни почетак и развој, битна је била велика љубав према српској књижевности која је била последица мог рођења на северној граници нашег народа (...) За мене је литерарни рад, у мојој младости, била нека врста националне дужности." (Црњански 1992: 59) Међутим, на крају разматрања ове теме, Црњански ће се оградити од оваквог схватања односа између нације и колектива. Он каже: „Моја књижевна схватања, данас, разликују се од мојих илузија тог времена" (Црњански 1992: 59). Па ипак, нешто касније, у истиом интервјуу, Црњански ће поновити мисао која више одговара његовом младалачком ставу према односу између писца и колектива, него овом, новом, „зрелом”. Црњански каже: „Књижевник који не саучествује у судбини свог народа није прави књижевник. Нарцисист у литератури спада у категорију литерарних онаниста" (Црњански 1992: 62).

2 „Имајте на уму да сте ви весник истине. По вама велика и сложена људска стварност шаље своје поруке. Она вас је издвојила од осталих људи утолико (и само утолико!) што вам је поверила важно послање да људима вашег језика изнесете пред очи слику и смисао, развитак и правац одређене стварности коју они само кроз уметничко дело могу у целости да сагледају и потпуно схвате" (Андрић 1975: 251). 
тематизовање нестанка народа у Хазарском речнику. Сви ови примери указују на континуитет разумевања књижевног стварања у оквиру једног колектива као и свест о повезаности књижевног стварања са тим колективом и његовом судбином. Притом, поновимо, овај однос не доводи до тога да колектив угуши индивидуалност појединца: сасвим супротно, обавеза према колективу омогућава појединцу да постане личност (в. Владушић, 2017) односно да превлада опозицију појединац-колектив. Личност је, дакле, писац који осмишља концепт колектива, који тематизује његову историју, његову судбину, његову будућност, а да при том сам колектив такву улогу личности не само разуме, већ и прихвата. То јесте специфичност српске књижевности: са једне стране, у њеној историји може се распознати управо таква улога личности писца, док са друге стране, то значи да у књижевном пољу српске књижевности постоји једна квантитативно и квалитативно значајна група читалаца која управо тражи да књижевно дело прихвати ту врсту обавезе. ${ }^{3}$

3 Остаје отворено питање у којој мери је ова особина српске књижевности карактеристична и за друге европске и светске књижевности. Вероватно је да српска књижевност није једина у погледу овог својства, али је сигурно да постоје другачији концепти односа између књижевности и колектива у коме настаје. Примера ради, када се на једном месту у Роману о Лондонупримети да је сада време „криминалних романа” (Црњански 1996: 232) то сигнализира два ствари: 1) да највећи број читалаца у Енглеској књижевност види пре свега као средство забаве, 2) да не постоји неки другачији концепт књижевности, који има своју читалачку публику и моћ да се успостави као доминантан. Имплицитна напомена која расветљава лудички концепт књижевности у неолибералном Лондону/Мегалополису показује како писац постаје занатлија који производи робу за тржиште, што значи да су његови читаоци пре свега купци, а не ближњи, било у националном смислу (сународницима) било у филозофском смислу (људима са којима се дели иста егзистенцијална ситуација или исти дух времена). 
Постоји, међутим и друга група читалаца, ништа мање вредна или важна од ове прве, а то су они читаоци који књижевном тексту приступају као према уметничкој форми. Они у књижевном тексту посебну пажњу обраћају на семантику форме, на инвентивност формалних решења, на питање функционалности стила и његове естетске релевантности, на однос према књижевној традицији и канону, на поетичка одмеравања у односу на доминантни поетички дух епохе. У крајњем случају, ови читаоци акцентују (формално)иееоријски хоризонти читиань, који свој назив заслужује услед утицајности методолошких праваца проучавања књижевних дела који су доминантни у одређеном временском периоду.

Извесно је да најбољи читаоци обједињују особености обе читалачке групе; они показују да уистину не постоји разлог због чега би неки читалац морао да се опредељује за један или други начин читања. Примењени истовремено, уз свест да је књижевност истовремено и уметничка форма али и јавни чин, ова два различита концепта се могу помирити. Међутим, такви случајеви су ипак прилично ретки: наведена подела ипак функционише (некада и у радикално заоштреном виду) зато што читалачка компетенција није неки објективно задати кодекс, већ њена природа зависи од наклоности онога ко је обликује и дистрибуира. Најзад, ни историја методолошких праваца проучавања књижевности није историја мудрог усклађивања разноликих праваца проучавања књижевног дела, већ пре функционише као низ методолошких удара или експлозија који теже да створе ефекат, новог, револуционарног дисконтинуитета у традицији проучавања књижевности. Као и свака друга револуција, ни ова нема милости према претходним, затеченим традицијама читања.

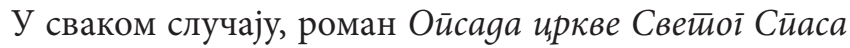
успео је да у себи уједини и један и други начин читања, и то не у форми неког трулог компромиса, када би и један 
и други тип читаоца осетио нелагоду због присуства оноі̄ gpyīoī. Напротив, Петровићев роман за оба типа читања остаје компактан и неупитан. Управо зато Oйcaga uркве

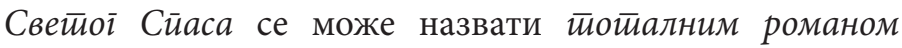
српске књижевности 20. века, при чему формулација йойални роман упућује и на темпоралну дубину имагинарног света који повезује средњи век и савременост, па тако полаже право на тоталитет времена, али и на тоталност херменеутичких позиција насталих на различитим методолошким правцима и концепција књижевности на које овај роман позитивно реагује.

При томе, било би апослутно погрешно помислити да је оваква тотална природа Петровићевог романа последица неке ауторове прорачунатости. Напротив, ако би требало да одаберем метафору која одређује процес Петровићевог писања Oūcage, била би то слика античког певача кроз кога проговара божанство. А такви су певачи, као што знамо, били веома ретки. И веома поштовани. Такво поштовање заслужује и Горан Петровић, ван сваког спора.

Сада је време да се постави и једно бласфемично

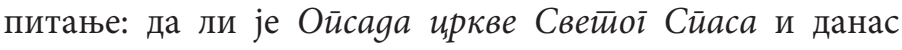
култни роман? На први поглед, одговор на ово питање је потврдан, уколико прегледамо програме студија српске књижевности 20 века. То могу да потврдим из личне предавачке праксе: ја предајем студентима Петровићев роман и то са великим задовољством. Па ипак, и поред ове институционалне канонизованости, ово питање захтева примеренији одговор: вредност коју брани само институција, јесте вредност која то више није. Зато питање треба оставити отвореним, посебно у контексту пропитивања концепта српске књижевности коме управо присуствујемо.

Наиме, ако је Петровићев роман свој култни статус стекао услед чињенице да је био у стању да уједини два 
захтева упућена прози - 1) епски захтев, захтев осећања обавеза према националној судбини, као и 2) формални захтев, захтев за релевантношћу саме књижевне форме, онда велики значај има чињеница да неолиберални кон$\overline{\mathcal{u}} е к с \overline{\mathcal{u}}$ савремене српске државе активно негира оба ова захтева, креирајући један потпуно другачији концепт књижевности. Наиме, Бурдије неолиберализам одређује као „програм за методичко уништавање колективног” (Бурдије 2014: 24) из чега закономерно произилази укидање епског захтева који је српска књижевност до сада спремно испуњавала, будући да се тај епски захтев тицао управо самосвести колектива о самоме себи. Исто тако, извесно је да је доминантан концепт књижевности који данас влада на Западу, померио правац интересовања са текста на контекст, што доводи до маргинализације формалног акспекта књижевности у корист његове репрезентативно-идеолошке улоге. Укратко речено, у неолибералној држави књижевност може бити или роба или гест политичког активизма који легитимише неолиберални концепт фрагментарне заједнице, при чему, у реалности, књижевно дело може да буде и роба и гест политичког активизма.

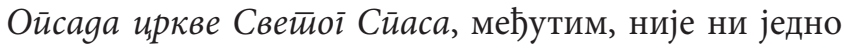
ни друго.

Описана промена концепта књижевности је толико радикална да се поставља оправдано питање: да ли ће се и на који начин у том новом, промењеном концепту читати Петровићев роман?

Први могући одговор на ово питање јесте тај да се

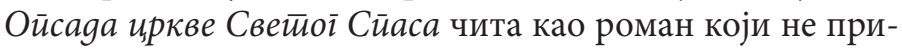
пада не само неолибералном концепту књижевности већ исто тако и неолибералном духу времена. То би онда значило да се Петровићев роман претвара у неку врсту азила Традиције за коју више нема места у савременом свету. Симболички, сам роман би био у том смислу опседнут 
као и црква Светог Спаса. Разуме се, такво читање би било сасвим легитимно. Међутим, евентуална предоминантност овакве рецепције Петровићевог романа указала би на то да је овај роман просто изван свог времена, и да он о овом времену нема шта да каже. Парадоксално, вредности које би на тај начин настојао да сачува - примера ради, вредности које се тичу сфере средњевековног наслеђа или наслеђа усмене књижевности - биле би на тај начин, симболички већ искључене из овог света.

Да се то не би догодило, било би нам потребно једно заиста ново читање Петровићевог романа. Заиста ново

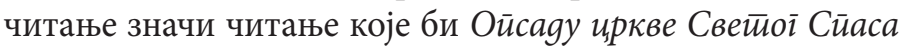
повезало са духом нашег времена. Ако би такво читање било могуће, то би онда значило да Петровићев роман још увек има ту моћ да осветли дух времена у коме се рецепира и то на начин на који је недостижан савременој књижевности која настаје под императивима политичке коректности и профитабилности, а то значи свесно дистанцирана од сенки савременог света. Таква сазнајна функција овог романа, која наравно, не би била могућа без естетске релевантности књижевног текста, нужно би повезала савременог читаоца и Петровићев роман, јер би му роман нудио привилеговану спознају савремености. Када кажемо привилеговану, мислимо на ону незамењиву моћ књижевности да не само осветли неки феномен епохе већ и да га учини важним за живот читаоца. То је моћ књижевности којом се она, можда, још може супротставити диктату тржишта и политичке коректности.

За крај овог текста покушаћемо да скицирамо само

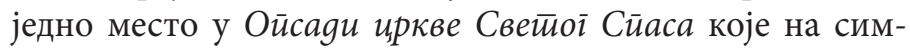
болички начин проговара о нашем времену. То место је феномен минијат̄уризације који се појављује у имагинарном свету Петровићевог романа.

Најпре, оквирна дефиниција: минијатуризација је феномен који наглашава диспропорцију између вели- 
чине и значаја појединих предмета. Изузетно мала ствар, добија изузетно велики значај. Најбољи, али не и једини пример за феномен минијатуризације је кључни мотив романа - анђеоско перо. Огромна важност овог пера у имагинарном свету романа налази се у диспропорцији са његовом физичком величином.

Када се једном установи као лајтмотив, феномен минијатуризације постаје структурно начело имагинарног света Петровићевог романа, које се потом понавља у различитим симболичким равнима. Таква је на пример сцена у трећем одељку 12. дана у којој млетачки дужд Енрико Дандоло тражи од младог принца Алексија, претендента на византијски престо, као плату за подршку, само један прост огртач састављен од десет хиљада различитих птичијих пера. Алексије је зачуђен зато што не зна за велику вредност овог огртача, која је опет сасвим диспропорционална његовом скромном изгледу, али дужд врло добро зна шта тражи и колика је вредност онога што тражи. На тај начин се у имагинарном свету

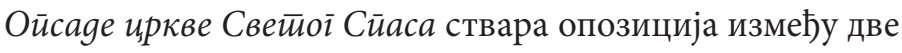
групе јунака: оних који су свесни вредности које имају поједини предмети упркос њиховој привидној безвредности и оних који те вредности нису свесни. Другачије формулисано: постоје јунаци чија слика света превазилази очигледност и јунаци чија се слика света завршава у сферама очигледног; ова разлика би се могла изразити и као разлика између јунака који тумаче свет и оних којима моћ тумачења (схваћена као сагледавање онога што није очигледно) једноставно није дата.

Феномен минијатуризације који се у форми лајтмотива појављује у Петровићевом роману, упућује нас на нашу савременост. Да би се такав домашај овог феномена уочио, најпре је потребно указати на то чему је минијатуризација у светско-историјском погледу супротстављена. Одговор на ово питање води нас до Бахтиновог читања 
Раблеа. Анализирајући имагинарни свет романа француског ренесансног писца, Бахтин уочава један важан образац: „... све што је вредно, вредносно позитивно мора остварити свој вредносни значај у просторно-временском значају, распростирати се што је могуће даље, постојати што је могуће дуже: све што је стварно вредносно значајно неизбежно је обдарено и снагом за такво такво просторно временско ширење; а све што је вредносно негативно мало је, јадно и немоћно, и мора бити потпуно уништено и неспособно да се супротстави својој пропасти" (Бахтин 1989: 287).

Овај образац није разуме се, карактеристичан само за Раблеа. Поменути образац представља ренесансни или модерни одговор на хришћанску слику света у коме предмет своју важност или вредност не добија из сопствене величине или дужине протежности већ из симболичке везе са оним невидљивим - Богом. Супротни образац, образац у коме вредност почива на величини и количини, дакле на оном видљивом, последица је опадања значаја Невидљивог и одушевљења модерног човека овим, дакле, видљивим светом, светом извесности, а не светом веровања.

Може се рећи да је образац поистовећивања величине/количине и вредности функционисао све до краја Другог светског рата, када се почео наслућивати његов завршетак. Епохални догађај у том смислу било је америчко бомбардовање Хирошиме и Нагасакија. То је био први гест минијатуризације и то у најмање у два смисла. У првом, то је огромна диспропоција између узрока (једна бомба) и последице које је та једна једина бомба начинила. Други моменат тиче се спреге између овладавања микро- светом (светом атома) и овладавања макро-светом; ко контролише микро-свет, свет невидљив људском оку, тај влада макро-светом.

Овај други смисао минијатуризације постаје временом све јаснији: моћ данас више није сконцентрисана у 
количини оружја или величини тенкова, авиона, топова, па чак и ракета, већ у овладавању микропростором простором људских гена, простором нанотехнологије, сајбер простором. Показује се, све јасније, да огромни системи имају ахилове пете, односно да се су неотпорни на диверзије у микро-простору: примера ради, милиони људи данас могу да умру од вештачких вируса који су људском оку невидљиви.

Феномен минијатуризације се из простора науке незамисливе Раблеу и његовим читаоцима - тако шири и у простор историје и политике у коме је донедавно такође био незамислив. Други светски рат је решен исходом сукоба колосалних размера између немачког Вермахта и совјетске Црвене армије, у коме су учествовали милиони војника, хиљаде авиона и тенкова и десетине хиљада топова. Пола века касније, СССР, победник у том рату раблеовског простирања, распао се без и једног јединог испаљеног метка, на први поглед, сам од себе: распао се зато што је свест његових грађана била тако темељно промењена у једном минијайурном рату. Постоји једна анегдота која свој шарм дугује управо феномену минијатуризације: СССР је пропао зато што није умео да направи фармерице. Анегдота би била глупа да нема концепта минијатуризације који јој даје смисао. Колосални пораз огромних последица - распад СССР-а - догодио се као последица пораза у једном невидљивом рату за људску свест и за њену слику света, који се одвијао и на пољу гардеробе, где су наоко скромне, радне панталоне америчких фармера, одједном добиле неслућену снагу и значај попут оног плашта од десет хиљада пера које је тражио Енрико Дандоло. Поред тврде моћи оружја, постоји дакле и невидљива мека моћ, моћ утицаја на људску свест преко свега што може да има симболичку, конотативну, дакле, невидљиву снагу, коју већина људи не може да види, нити може да докучи процесом тумачења који им је такође стран. 
Наш данашњи свет више није свет ренесансног човека попут Раблеа, који је одвећ био загледан у оно видљиво; наш данашњи свет је свет минијатуризације, свет у коме моћ има и своју невидљиву компоненту.

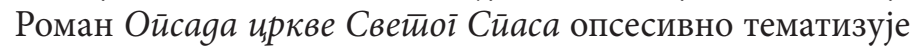
феномен минијатуризације, наоко као необавезну игру маште, а заправо у форми врхунског сазнајног инструмента, једног литерарног микроскопа који има ту моћ да увећа нашу епоху до оне тачке када невидљиво постаје не тек видљиво, већ увеличано, очигледно.

\section{ЛИТЕРАТУРА}

Андрић, 1975: И. Андрић, „Белешке писцу”, у: М. Недић (ред), Срйска книжевна критиика, Писии као криитичари йосле

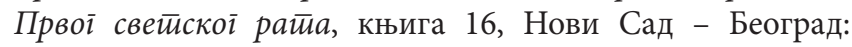
Матица српска, Институт за књижевност и уметност, 248 $-252$.

Bahtin 1989: M. Bahtin, O romanu, Beograd: Нолит.

Бурдије 2014: П. Бурдије, „Суштина неолиберализма”, Злайна iрpega, новембар -децембар, Нови Сад, 24.

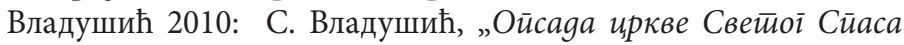
и историографска метафикција", Гоgишюак Филозофскоі факулиетей у Новом Саgу, књига XXXV, Нови Сад, 121130.

Владушић 2017: S. Vladušić, Književnost i komentari, Beograd: Službeni glasnik.

Јовановић 2012: T. Jovanović, „Istoriografska metafikcija u romanu Opsada crkve Svetog Spasa Gorana Petrovića” y: S. Gudurić (ред) Jezici i kulture u vremenu i prostoru, tematski zbornik I, Филозофаски факултет, Нови Сад, 611 - 618

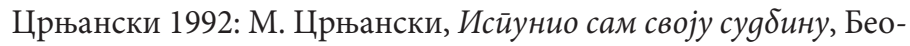
град: БИГЗ, СКЗ, Народна књига.

Црњански 1996: М. Црњански, Роман о Лоняону, Београд: Просвета. 
Slobodan Vladušić

\section{WHY DO WE NEED A NEW READING OF OPSADA CRKVE SVETOG SPASA?}

\section{Summary}

The text first poses the question of understanding the cult status of Goran Petrovićs novel Opsada crkve Svetog spasa. According to our opinion, that status is a consequence of the fact that Petrovićs novel had managed to reconcile two seemingly different understandings of literature: the epic, which asks from literature to be responsible for self-understanding of the collective and formal-theoretical, which is based on a dominant theoreticalpoetic horizon of expectation. During the 1990s, that horizon was based on a postmodern stance towards history through the genre of historiographical fiction. The text then reiterates the question whether Petrovićs novel still has its cult status today, since the concept of Serbian literature is being transformed in the spirit of neoliberalism which perceives literature as a commodity and/ or a gesture of political activism, which bring to doubt both the epic request to unite the collective as well as the formal-theoretical horizon of reading. The text offers a possible answer to this question: if Petrovićs novel is to preserve its cult status in the new concept of literature, it must generate a novel reading. This new reading should confirm its status as a learning tool which speaks of our (neoliberal) epoch. The last part of the text ushers in a blueprint of such a reading of Opsada crkve Svetog Spasa in which special attention is given to the leitmotif of miniaturization which is present in this novel and which is a trait of our epoch.

Key words: the epic, formal-poetic horizon, poetics, neoliberalism, miniaturization 